\title{
Promoting Green Jobs: Decent Work in the Transition to Low-carbon, Green Economies
}

\author{
Kees van der Ree
}

\begin{abstract}
This chapter explores the nexus between climate change and jobs. For the International Labour Organization (ILO), the relevance of climate change and low carbon development has not always been evident. Member states and social partners have long been reluctant to include the transition to low carbon economies in the programme of work and commit resources to it. But in recent years, environmental issues have become a policy priority among ILO member states and social partners. Why, then, is climate change now more relevant than ever for the world of work? What are the current and forecasted employment and social implications of climate change and the policies for adaptation and mitigation? How can the distributional impact of the move to a low-carbon society be better understood and managed? In this respect, how relevant is the concept of 'green jobs'? What policy approach has emerged within the ILO despite initial resistance and disagreement among constituents? Finally, what role could the ILO play in the future to promote social justice in the transition?
\end{abstract}

\section{1 \\ Introduction}

The International Labour Organization(ILO) has addressed the relationship between the environment and employment on several occasions in its past, with peaks of attention occurring at the rhythm of subsequent international environmental conferences (1992, 2002 and 2012). Its contributions argued for a better reflection of the social dimension in the agenda for sustainable development. Still, for many years these efforts remained peripheral relative to the attention on standard setting and social dialogue - the core functions of the Organization.

Over the last decade, in parallel to the growing international concern over climate change and resource scarcity, the issue has gained importance within the Organization - albeit not without initial resistance. This chapter first explores the relevance of the employment and social dimension of climate

(C) KEES VAN DER REE, 2019 | DOI:10.1163/9789004399013_013

This is an open access chapter distributed under the terms of the prevailing CC-BY-NC license at the time of publication. 
change. It introduces the concept of 'green jobs' and argues how it can be used to improve the understanding of the potential losses and gains resulting from dedicated policies to address the effects of climate change. It then discusses the need for and features of policies to ensure a just transition and examines how the ILO has recently shaped its support to the design and implementation of such policies.

The chapter then offers a more introspective view on how the ILO as a tripartite institution has incorporated environmental sustainability as a policy priority in all its areas of work. It argues that the initial resistance among some member states and the benign ignorance among others have been overcome thanks to the growing international concern about climate change and the persistent advocacy of one of the social partners. Finally, it concludes that the Organization's mandate to promote social justice compels it to provide global leadership for a just transition towards environmental sustainability as an indispensable element in its future policy agenda.

\section{The Relationship between Climate Change and Employment}

Rising temperatures and erratic weather patterns are directly affecting the lives and income sources of many people. The number of people displaced by floods and environmental degradation is rising year after year. It is generally believed that as many as 200 million people could be compelled to migrate permanently by 2050 due to the physical effects of climate change (Brown, 2007). Higher seasonal temperatures are posing a health risk to more and more workers in outdoor occupations, such as in agriculture, construction, infrastructure development and those engaged in informal street trading and food vending. According to the issue paper 'Climate Change and Labour: Impacts of heat in the workplace' (UNDP, 2016), peak temperatures could reduce working hours during the day by up to 5 per cent in countries such as Bangladesh, India and Pakistan, even if the global temperature rise can be limited to $1.5^{\circ} \mathrm{C}$. This, added to rising air pollution in densely populated cities, has far-reaching implications for job quality and productivity.

Clearly, climate change and environmental degradation have repercussions on employment. If, on the one hand, there are negative effects on working conditions and job security in exposed areas, adaptation measures, on the other hand, can in themselves be a source of job creation, notably in building sustainable infrastructure, or through adding planting and harvesting cycles. 
Mitigation policies also have significant effects on jobs, both in negative and positive ways. Energy policies that aim to reduce dependence on coal and the current wave of disinvestment in coal mining by large financial institutions, for example, have led to job losses in particular geographical areas and among specific parts of the work force. But mitigation can also drive job creation, for example through investment in renewable energy, eco- and energy-efficient ('green') construction, or improved waste management.

Realising the economic and social linkages between climate change and employment, national policymakers and international organisations have begun to recognise this nexus and have adopted policies to address it. As the ILO Director General wrote in his report to the 106th International Labour Conference, there is ample 'evidence that the transition to an inclusive green economy can indeed act as a new engine for growth and a strong driver of decent work creation in developing, emerging and advanced economies' (ILO, 2017a, 8). However, he also acknowledged that this outcome is not guaranteed. Indeed, the jobs in a greener future will not be decent by default, but by design (ILO, 2017a). Such an outcome requires economic and social policies that help workers to adjust, including large-scale investment in education and training systems at the secondary and tertiary levels.

This reflection of the importance of climate change for the ILO's future agenda is fundamentally different from the place environmental sustainability had in the Organization in the past. The Brundtland Report in 1987 and the United Nations Conference on Environment and Development (UNCED), or Earth Summit, in Rio de Janeiro in 1992 triggered more interest among the ILO's constituents and within the Secretariat for addressing the implications of environmental challenges for the world of work (ILO, 2017a). As a result, the ILO began contributing to the adoption of global conventions on occupational safety and health issues directly related to environmental hazards and risks. ${ }^{1}$

However, it took a good 20 more years before the ILO embraced the need to address climate change as relevant for its own work. After the adoption of full employment and decent work as a global goal by the World Summit on Social Development in 2005, a set of indicators on employment were brought into the Millennium Development Goals (MDGs) framework. The Director General proposed, in his report to the 2007 International Labour Conference, 'Decent Work for Sustainable Development', to set up a programme of work for 'promoting a socially just transition to green jobs' (ILO, 2007, 2). In subsequent years the climate change agenda began to gain ground across constituents and ILO programmes, albeit with initial reservations from a number of constituents.

1 See, for a summary, http://www.ilo.org/safework/areasofwork/chemical-safety-and-the -environment/WCMS_118357/lang--en/index.htm (accessed on 11 June 2018). 


\subsection{Defining and Contextualising 'Green Jobs' ${ }^{2}$}

Over the past decade there has been a continuous flow of studies, reports and articles about the nature, quantity and quality of green jobs; a useful overview is provided by Bowen and Kuralbayeva (2015), concluding that despite a myriad of empirical reviews there remain considerable methodological flaws.

Green jobs can be viewed from two perspectives: through the lens of final output or through production processes. From an output perspective green jobs generate goods or provide services that benefit the environment. Examples include green buildings, clean transportation or solar-powered water-heating systems. The jobs involved are viewed as green even though the outputs may not be based on 100 per cent environmentally friendly production processes and technologies.

On the other hand, jobs can be green when they contribute to more environmentally friendly processes-for example by reducing water consumption, controlling air pollution or improving recycling services. Again, green jobs defined in terms of production processes do not necessarily produce 100 per cent environmentally friendly final goods or services.

As shown in Figure 12.1, green jobs do not automatically constitute decent work. Many current recycling jobs, for instance, recover raw materials and thus help to alleviate pressure on natural resources. These jobs would be in Circle A. However, the jobs involve a working practice that is often dirty and dangerous, causing significant damage to human health. Employment in this industry tends to be precarious and unprotected and workers' earnings are low. To be truly classified as green jobs, labour conditions need to meet decent work criteria ${ }^{3}$ (i.e. overlapping with Circle $C$ in Figure 12.1). Thus, in the case of waste management, jobs would be 'green' if social protection measures were accessible and safety and health at work were ensured, whilst some kind of labour agreement lent employment security to workers engaged by collection companies. In the same vein, jobs involved in ensuring resource efficiency in bottling companies, for example, or applying clean production methods (Circle B), should meet decent work criteria if they are to qualify as 'green jobs'.

2 This section largely builds on van der Ree (2017).

3 The ILo's definition of decent work includes (i) opportunities for work that is productive and delivers a fair income, (ii) security in the workplace and social protection for families, (iii) prospects for personal development and social integration, (iv) freedom for people to express their concerns, organise and participate in the decisions that affect their lives, and (v) equality of opportunity and treatment for all women and men (see the website https:// www.ilo.org/global/topics/decent-work/lang--en/index.htm (accessed on 16 August 2018)). 


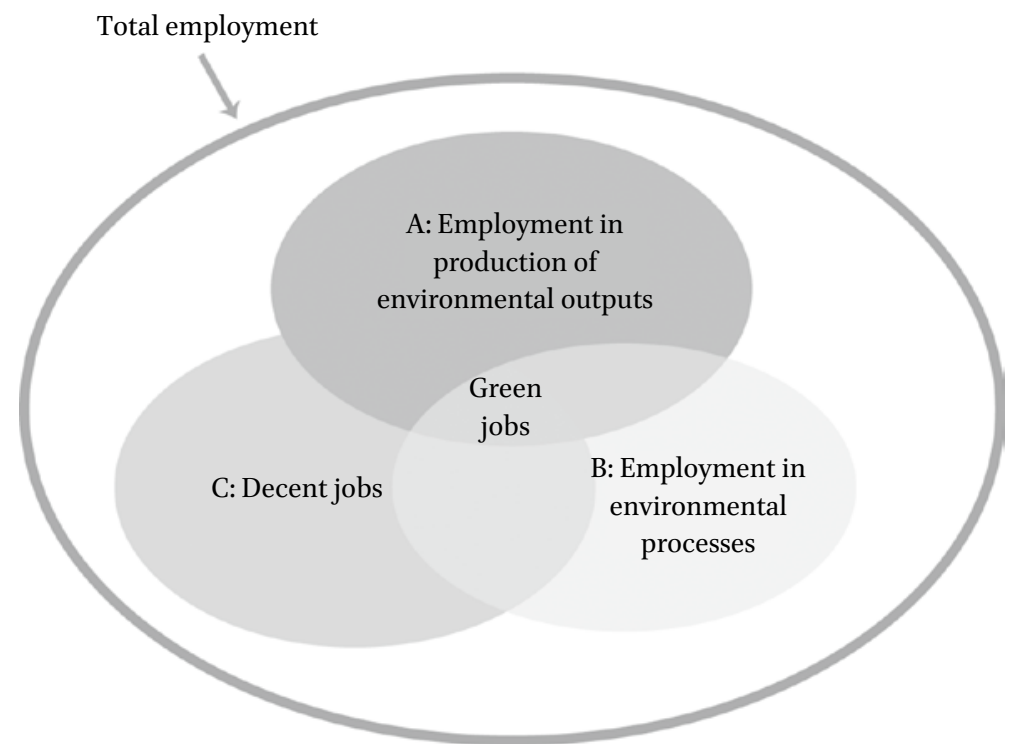

FIGURE 12.1 The Relationship between the environment and employment SOURCE: ILO (2013a).

The inclusion of the decent work dimension in the concept of jobs linked to environmental sustainability is the defining element of the ILO interpretation of green jobs (Box 12.1).

The concept of green jobs relates to employment in economic activities in the 'green economy' (UNEP, 2011) that (i) are low in emissions of greenhouse

\section{BOX $12.1 \quad$ ILO definition of green jobs}

Green jobs are decent jobs that contribute to preserve or restore the environment, be they in traditional sectors such as manufacturing and construction, or in new, emerging green sectors such as renewable energy and energy efficiency.

Green jobs contribute to:

- Improving energy and raw materials efficiency

- Limiting greenhouse gas emissions

- Minimizing waste and pollution

- Protecting and restoring ecosystems

- Adapting to the effects of climate change 
gases, (ii) are efficient in resource use, (iii) maintain biodiversity and ecosystems and (iv) enhance social inclusion. Ultimately such activities should result in improved human well-being and social equity, while significantly reducing environmental risks and ecological scarcities.

In the context of the Agenda for Sustainable Development and the outcome of the Rio+2o Summit, the green economy is positioned as 'one of the important tools available for achieving sustainable development [...] that should contribute to eradicating poverty as well as to sustained economic growth, enhancing social inclusion, improving human welfare and creating opportunities for employment and decent work for all, while maintaining the healthy functioning of the Earth's ecosystems' (UN, 2012, para. 56). This signals that the green economy and green jobs are means of achieving the goal of sustainable development, rather than being ends in themselves.

In a similar fashion green jobs can be viewed as instrumental to achieving the targets of several of the Sustainable Development Goals (SDGs). Although SGD 8 is the most explicit about employment ('to promote sustained, inclusive and sustainable economic growth, full and productive employment and decent work for all'), jobs and improved working practices are key to achieving several other goals, notably SDG 12 on sustainable consumption and production, or SDG 7 on ensuring energy access for all.

The significance of social and employment factors that determine the successful achievement of sustainable development has been highlighted by a range of international agencies, notably the United Nations Research Institute for Social Development (UNRISD). In its contribution to the Rio+2o Conference (UNRISD, 2012), it argued for shifting the policy focus towards a 'social green economy'. This would require a more balanced policy approach between (i) providing compensatory measures for those negatively affected, (ii) maximising co-benefits in terms of green jobs, and (iii) fostering participation and ensuring rights. UNRISD also called for social policies that underpin environmental investments such as those in public transport systems or in retrofitting housing for energy efficiency, as well as for capacity building to access and use green economy technologies.

A more conscious effort to assess and correct the negative social impact of the green transition could also enable greater gender equality (ILO, 2017c). Green jobs are not by definition more or less accessible to women. However, environmental policies can have gender-balance repercussions due to the different sectoral impacts of low-emissions strategies. Men are more affected in shrinking extractive industries with predominantly male workers, and men are more likely too to become engaged in green construction. Women may benefit more from the growth of organic horticulture or waste management 
in countries where the related workforce is female-biased. Investment in renewable energy in rural areas may ease the task for women to provide energy for the household. Dedicated, gender-sensitive labour market policies can play an important role in facilitating the adjustments and ensuring that environmentally sustainable jobs are decent and provide real opportunities for women.

The report by the Organisation for Economic Co-operation and Development (OECD) 'Investing in Climate, Investing in Growth' (OECD, 2017) acknowledges that the goal of reducing emissions can only be reached if governments take fully into account the social and economic factors that determine the success of ambitious climate policies. It argues for ensuring an 'inclusive transition' based on dialogue and consensus building among stakeholders, and stresses the importance of adopting active labour market policies to guide and facilitate the change. Similarly, the Global Green Growth Institute (GGGI) has included job creation as one of the six strategic outcomes of its refreshed mid-term strategy (GGGI, 2017). These are illustrations of the broad consensus that has emerged over the last six years or so from earlier negligence-at best-among international organisations regarding the key importance of the employment dimension of climate change action.

\subsection{The Employment Effects of Environmental Policies}

The visualisation of green jobs in Figure 12.1 also helps us understand the dynamic relationship between economic development and environmental sustainability. Recent sector studies using modelling techniques based on available statistics show how expanding sectors such as renewable energy provide for new job opportunities. In addition to the jobs directly created, employment will expand along supply chains and in service sectors. The incomes earned and consequently expanded consumer demand will induce yet more jobs. Together, the modelling suggests that this would add up to the aggregate job gain stemming from an investment in renewable energy (Montt et al., 2018). Long-term effects on employment can be even more positive if the productivity and growth of certain categories of enterprises increase, such as for small and medium-sized enterprises (SMEs) in rural areas, which would become connected to national electricity networks, or farmers adopting resource-saving technologies using local renewable energy sources.

Environmental regulation and new technologies regarding cleaner production, emissions reduction or nature conservation can in principle contribute to the creation of green jobs. However, they may also risk stifling economic activity or lead to the relocation of enterprises. In the latter case, the implications for workers and their families need to be anticipated and managed 
through supportive labour market measures and social protection. This is particularly relevant in the energy and transport sectors.

Taken together, employment experiences multiple effects of climate change and the policies designed in response to it. Four types of changes in the labour market can be identified in Table 12.1 below.

TABLE 12.1 Current and expected effects on employment of climate change and green economy policies

\begin{tabular}{|c|c|c|c|}
\hline & Effects & Examples & $\begin{array}{l}\text { Expected } \\
\text { scale }\end{array}$ \\
\hline 1 & $\begin{array}{l}\text { New jobs will } \\
\text { be created (in } \\
\text { existing and } \\
\text { new } \\
\text { occupations) }\end{array}$ & $\begin{array}{l}\text { Solar panel technicians, organic farmers, recy- } \\
\text { cling managers, staff in eco- } \\
\text { tourism resorts, workers in natural resource } \\
\text { conservation and restoration, environmental } \\
\text { advisers, workers in bicycle shops. }\end{array}$ & Modest \\
\hline 2 & $\begin{array}{l}\text { Certain jobs } \\
\text { may be eliminated }\end{array}$ & $\begin{array}{l}\text { Coal miners, worker in bottling } \\
\text { industry adopting water and } \\
\text { material-saving technology, staff of obsolete } \\
\text { or prohibited packaging materials industry. }\end{array}$ & Small \\
\hline 3 & $\begin{array}{l}\text { Jobs will be } \\
\text { substituted (occu- } \\
\text { pations change) }\end{array}$ & $\begin{array}{l}\text { Jobs in transport systems moving to rail, elec- } \\
\text { tric cars and shared vehicles, waste manage- } \\
\text { ment jobs in landfilling/dumpsite moving to } \\
\text { incineration } \\
\text { and recycling, jobs in quarries for } \\
\text { construction using new building } \\
\text { materials and re-use of left-overs } \\
\text { and waste. }\end{array}$ & Modest \\
\hline 4 & $\begin{array}{l}\text { Most jobs will be } \\
\text { transformed (oc- } \\
\text { cupational profiles } \\
\text { change) }\end{array}$ & $\begin{array}{l}\text { Workers, operators and managers in green- } \\
\text { ing sectors notable buildings, agriculture or } \\
\text { transport: all learning } \\
\text { to manage new technology and } \\
\text { operating practices; workers in all sectors } \\
\text { where energy and resource efficiency is in- } \\
\text { troduced (cleaner production in manufactur- } \\
\text { ing, retail services without packaging, bottle } \\
\text { companies changing to new materials and } \\
\text { products), staff in financial } \\
\text { institutions adopting sustainable investment } \\
\text { strategies. }\end{array}$ & Large \\
\hline
\end{tabular}

SOURCE: ELABORATED FROM ILO (2011). 
To guide policymakers and programme implementation, the ILO has undertaken a series of mapping studies to better understand and measure the impact on employment of climate change and policies for environmental sustainability. ${ }^{4}$ The ILO has published a Policy Brief (ILO, 2013b) and a Practitioners' Manual (ILO, 2017d) laying out the specifics and methodological steps involved.

The assessments - though similar in their objective-are unique, as they each follow a consultative approach with stakeholders to distinguish 'green' jobs from others in each key sector (see Box 12.2).

\section{BOX 12.2 Green jobs assessment, Mauritius}

In support of Mauritius's 'Ile Durable' initiative, the ILO supported an assessment of the prevalence and potential of green jobs in the country. It used the input-output table 2009 from the Statistics Office, disaggregated into sub-sectors defined as 'green', such as green agriculture, sustainable fishing, green textiles, recycling, green hotels, sustainable transport, or renewable energy. The analysis considered green jobs from three perspectives: (i) jobs that add value to green products and services, (ii) jobs in greening processes, and (iii) jobs contributing to natural resource conservation.

The study revealed that there are 35,00o green jobs in Mauritius, or 6.3 per cent of total employment. Most green jobs were found in electricity generation, with 23 per cent of jobs involving supplying bagasse from sugar cane production to electricity plants. In agriculture, 12 per cent of employment was considered green as well as decent. In textiles only around 5 per cent of employment was found to be green.

The potential for green jobs was modelled using output and employment multipliers for green sub-sectors in agriculture (sugar), manufacturing (textiles), tourism (hotels) and energy (renewable versus fossil fuel), thus evaluating the direct and indirect effect throughout the economy. Projecting an annual growth rate of 2.5 per cent of total output, 21,60o new green jobs would be created. This compares favourably to 15,250 jobs when assuming business-as-usual growth without increased green products and processes. In particular, the increase in employment in the renewable energy scenario would be twice as much as the effect of simulated output growth in the fossil fuel sector.

4 These include studies of China, Bangladesh, Mauritius, South Africa, Kenya, Senegal, Zambia, Tunisia, Namibia, India (State of Gujarat), Malaysia, the Philippines, Indonesia (forestry), Mexico, Uruguay, Peru and Argentina. 
The differences between the green and the conventional growth scenario - as illustrated in the renewable energy sector-are due to the higher integration of green industries, and notably renewable energy-based activities, through linkages into the value chains of the Mauritian economy. Conversely, fossil fuels are imported and have much weaker linkages into the domestic economy, therefore generating less additional employment and value added in the country.

SOURCE: ILO (2015a).

The number of and trends regarding jobs related to environmental goods and services have been documented for a growing number of countries. For the US, the Bureau of Labor Statistics has concluded that, in 2010, the United States had 3.1 million green goods and services (GGS) jobs. GGS jobs accounted for 2.4 per cent of total US wage and salary employment (Bureau of Labor Statistics, 2010).

For the EU, a recent review asserts that the share of green jobs (defined as employment in the environmental goods and services sector) in total employment increased by around 37 per cent from 2002 to 2011 (Pociovălișteanu et al., 2015). In 2012, around 4.2 million people across the European Union (EU) were employed full-time in the environmental goods and services sector, with a large share of these jobs found in natural resource management. A panel review with data for EU countries from 2005 to 2013 shows that the growth rate has been positive in almost all countries, with the share in overall employment reaching 2 per cent. A particularly rapidly growing sector is waste recycling, with an increase of 45 per cent in 2000-07 (Altenburg and Assmann, 2017).

Other international organisations have become more active in monitoring trends and providing forecasts regarding employment in the green economy. One such example is the renewable energy sector, which is rapidly growing worldwide in terms of output. The International Renewable Energy Agency (IRENA, 2018) reports annually on global employment trends in renewable energy and asserts that global employment has grown substantially in recent years reaching an estimated 10.3 million jobs ${ }^{5}$ in 2017 (see Figure 12.2).

5 The estimates reflect annual data collection efforts based on a wide range of sources, including government agencies, industry and NGO studies, academic reports, and interviews with experts. Inevitably however, the underlying methodologies vary and data gaps remain. 


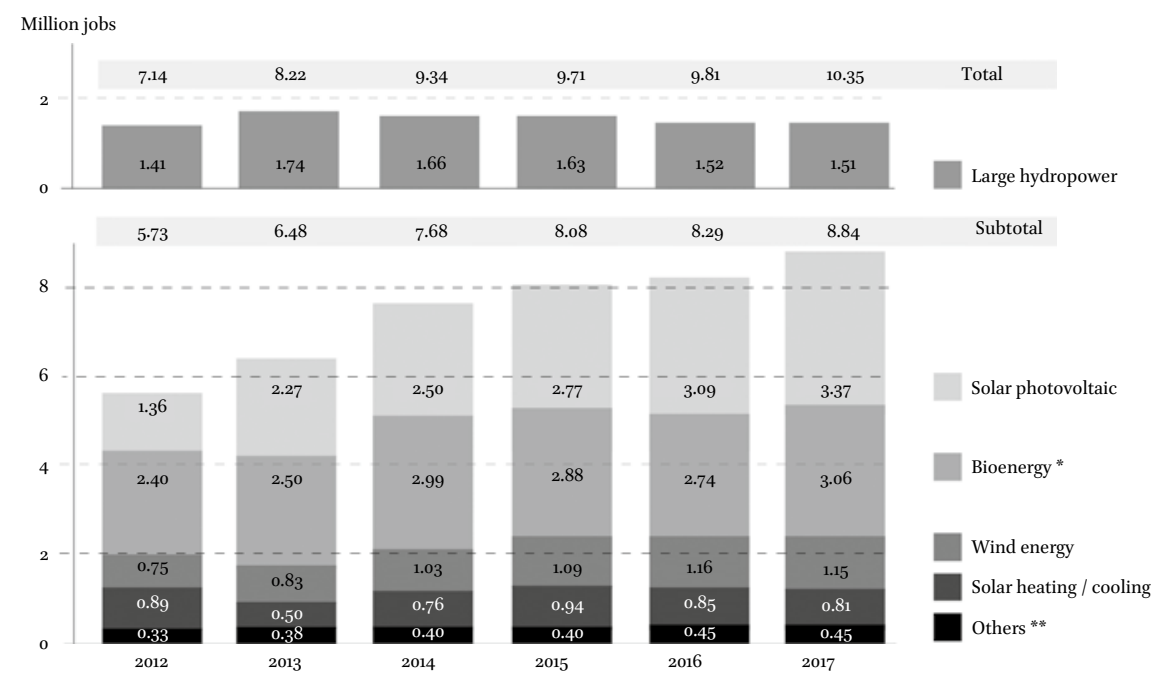

FIGURE 12.2 Global renewable energy employment by technology, 2012-17 SOURCE: IRENA (2018).

* includes liquid biofuels, solid biomass and biogas

** other technologies include geothermal energy, hydropower (small), concentrated solar power (CSP), heat pumps (ground-based), municipal and industrial waste, and ocean energy.

\subsection{The Skills Needed for Green Jobs}

The anticipated shifts in the labour markets of economies with carbon-intensive or high-emitting sectors will have a significant impact on skills needs. A global review of 21 countries, published by the ILO and the European Centre for the Development of Vocational Training (CEDEFOP) in 2011, found a frequent and significant gap between the skills levels required for jobs in green sectorsin particular renewable energy, green buildings, and manufacturing - and the training and competency standards provided by national vocational and tertiary institutions (ILO, 2011). This mismatch has effectively slowed down the advancement of green investment and enterprise development, as illustrated in countries such as Kenya, where 80 per cent of the technicians needed to build and operate a new wind farm - the largest in Africa-were recruited on the international market (PAGHC, 2017). Skills shortages, including those necessary for the creation and management of small enterprises, hinder the proliferation of investment in renewable energy in Africa in general, with only 30 per cent of the population having access to conventionally-generated electricity. In addition, skills training significantly enhances the employability and productivity of workers engaged in large-scale public employment programmes for environmental protection, such as evidenced by South Africa's 
Expanded Public Works programme ('Working For') and Brazil's Bolsa Verde initiative (UNFCC, 2016).

An increasing number of countries are adopting environmental legislation that makes reference to skills development. Recent national employment policies too include provisions for adapting skills systems, with more technical and vocational training for green jobs (van der Ree, 2017). An ILO survey of 2016 among 27 countries worldwide found that 19 had set up stakeholder platforms to anticipate skills needs and the provision of adequate training. But these efforts are hampered by a lack of consensus regarding the definition of skills for green jobs and by limited capacities for assessing the changing need for skills (ILO, 2018). Consequently, skills development policies in support of transition still have a short-term horizon and are implemented on a limited scale.

Countries with well-established labour market policies and effective Technical and Vocational Education and Training (TVET) institutions that are engaged with the private sector have adapted much quicker to the changing need for skills. In Germany and France, for example, the greening of the building sector has been much facilitated by a responsive training system adjusting curricula and introducing new green certification courses at an early stage.

\section{Managing the Transition for Enterprises, Workers and Communities}

The analysis of employment trends over the last decade undertaken by the ILO, the EU, the International Renewable Energy Agency (IRENA), the OECD and others consistently shows that employment in environmentally related sectors and industries is significant and, in many countries, growing. It also suggests that commitments to targets for emissions reductions consistent with the 2015 Paris Agreement and related policies and investments for green growth do not necessarily hurt jobs at the aggregate level. But the effects on labour markets will often be sector-specific and spatially concentrated in areas with resourceintensive industries. Many of these effects can be anticipated, but others may come as a relative shock when environmental policies change due to abrupt political changes.

Some policies will lead to the reduction of economic activity and value added in high-emitting sectors, hence leading to a loss of jobs. Whether the reallocation of workers towards alternative jobs in expanding industries, for example renewable energy, will offset this loss is dependent on factors such as the flexibility of labour markets, the alignment of incentives for investing and engaging workers in low-carbon sectors, and supportive measures by 
governments that seek to ease the transition. These challenges may be more important in emerging economies with a greater share of carbon-intensive industry, which also employ mostly low-skilled workers (OECD, 2017).

The ILO and OECD reviewed 24 available studies and the employment effect of environmental policies. They found that, in general, the net employment effects were positive, albeit modest. In countries where environmental policies were combined with well-designed supportive measures such as subsidies, fiscal incentives and sector promotion, as well as with active labour market measures, job outcomes were better (ILO and OECD, 2012).

The review also found that potential losses of employment were largely confined to high-emission, polluting industries, which often employ only a small portion of the total workforce. The top ten polluting industries, which are also responsible for the lion's share of emissions in the EU-25 countries, were only responsible for around 15 per cent of total employment (Figure 12.3).
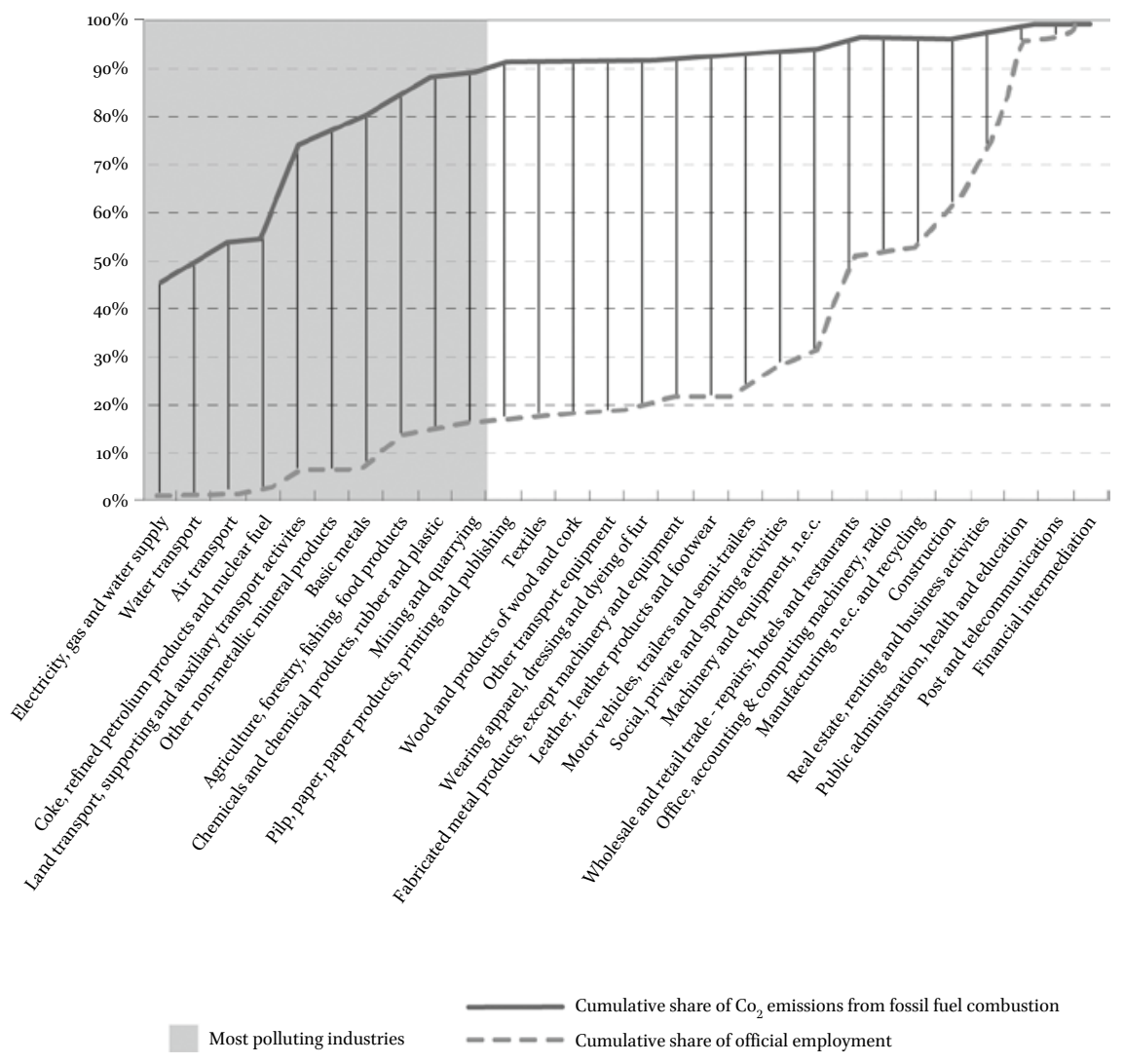

FIGURE 12.3 $\mathrm{CO}_{2}$ emissions and employment, EU-25, 2005

SOURCE: ILO AND OECD (2012). 
Further analysis of the educational profile and professional experience of workers in high-emitting industries shows that their skills level is generally lower. This implies that, for those workers, the transition to other jobs may be more difficult and possibly more costly in terms of unemployment payments, relocation and retraining (see Box 12.3).

\section{BOX 12.3 China's employment transition}

To address industrial overcapacity and achieve $\mathrm{CO}_{2}$ emission targets, the Chinese government ordered the closure of a series of coalmines, metallurgic industries and electricity companies in 2016 and 2017. As a result, at least 1.8 million workers employed in those industries would lose their jobs, with further negative effects on surrounding local economies due to the reduction in consumer demand.

At the national level, the government designed a package of measures. These included:

- A re-employment training subsidy, a start-your-business subsidy, enhanced public employment services, including job fairs.

- Early 'internal' retirement for workers less than five years away from retirement age, with enterprises remaining responsible for workers' 'subsistence' during these bridging years.

- Social protection and medical and pension benefits for employees of closing enterprises.

- Public Employment Projects to help individuals find re-employment, in which the government provides a subsidy for salaries and subsidies for social services.

In addition, the government induced enterprises to take on their own responsibilities by obliging them to absorb laid off workers, using new technologies and focusing on the enterprise-internal service sector. In return for these efforts, enterprises received preferential treatment and tax incentives. Enterprise-based HRD departments should undertake active labour market mediation, including helping individuals to start their own enterprises whilst keeping their formal labour relationship with the firm. These firms received subsidies for these start-ups.

The national government budget for these efforts stood at Yuan 10 billion (or US $\$ 1.5$ billion) in June 2017, to which funding from provincial governments was added. A total of 726,000 workers in 28 provinces and 2,00o enterprises have been re-employed or assisted in other ways since the measures came into force in 2016. Good examples, where a re-employment plan had been discussed and agreed before employees' contracts were terminated, 
include the iron and steel industries in the city of Wuhan, Hebei province, and the steel industry the city of Hangzhou, Zhejiang province.

China, having adopted green, clean development as one of the key priorities of its 2017-22 Development Plan, has begun addressing the particular challenge of the green transition.

SOURCE: VAN DER REE (2017).

For the US, the Political Economy Research Institute (Pollin and Callaci, 2016) has estimated the scope and costs of supporting the transition of workers and communities that are currently dependent on domestic fossil fuel production. Essentially, it calculated the budget required for (i) income, retraining and relocation support for workers facing retrenchments from fossil fuel based industries, (ii) guaranteeing the pensions of workers in the affected industries, and (iii) setting up effective transition programmes in affected communities.

Forecasting a downsizing of the US fossil fuel industry coherent with the $\mathrm{CO}_{2}$ emissions reduction targets set by the Intergovernmental Panel on Climate Change (IPCC), the impact on the supply chain and downstream energy production was calculated. Coal, gas and ancillary industries are, together, estimated to employ around 750,000 people. In the adopted emissions reduction scenarios around 450,000 jobs would be at stake. Of these, by far the greatest part-83 per cent of jobs - are held by workers who could retire in the projected period. The remaining 17 per cent would have to be redeployed in renewable energies or other sectors. Together with funding for the pension provisions of retired workers over the long term and transitional support for affected local economies and communities, the total cost would be USD 600 million per year.

The International Trade Union Congress (ITUC) has long advocated for a just transition. In 2016, it established the Just Transition Centre with the intention of being a clearing house and proponent of strategies and tools for national governments and local actors, with a focus on workers' organisations (ITUC, 2016). It intends to bring together workers, employers, communities and governments to undertake social dialogue in order to shape the pathway to a just transition, understood as 'an economy-wide process that produces the plans, policies and investments that lead to a future where all jobs are green and decent, emissions are at net zero, poverty is eradicated, and communities are thriving and resilient' (ITUC, 2017, 6). 
Indeed, there is a strong case for learning from earlier transitions, such as those related to coal mining. The Institute for Sustainable Development and International Relations (IDDRI) and Climate Strategies are leading a research and dialogue project on the future of coal. Their review includes cases from Spain, the UK, the Netherlands, the US, and the Czech Republic and Poland, and has included the drawing up of detailed policy recommendations to plan and manage the closure of mines (Caldecott et al., 2017). The ILO's Green Jobs programme is actively supporting the piloting of just transition approaches in a learning-by-doing approach in the Philippines, Ghana and Uruguay.

\subsection{ILO Support for a Just Transition}

Throughout its history, the ILO has promoted social justice in all major economic transitions. This mandate has shaped the role of the Organization in helping to ensure that economic growth policies generate opportunities for decent work and social protection for all —in other words are just and inclusive. In the current context of climate change, social justice underpins the imperative of a 'just transition' of the workforce and the creation of decent work and quality jobs, which are also reflected in the 2015 Paris Agreement.

The Green Jobs Initiative ${ }^{6}$ was launched in 2007 to promote opportunity, equity and a just transition to sustainable economies, using social dialogue to shape coherent policies for a green economy with green jobs and decent work for all. It led to the creation of a dedicated, resourced programme of work on Green Jobs in 2008, with a mandate to work across the ILO to raise awareness and rally support for the promotion of green jobs.

\subsection{Diverging Political Positions}

Even though the Green Jobs Initiative was conceived and driven by a tripartite ILO partnership together with the United Nations Environment Programme, the policy consensus with regard to the full integration of climate change in the work of the Organization still had to be forged. The differences among certain member states and the diverging positions of employers' and workers' organisations became visible in the debates at the Governing Body leading up to the Rio+2o Conference. A number of representatives of the G77 group, opposed to the terms 'green economy' and green jobs, suggested adopting the concept

6 A partnership between the International Trade Union Confederation (ITUC), the International Organisation of Employers (IOE), the ILO and the United Nations Environment Programme (UNEP). 
of sustainable development instead. ${ }^{7}$ The Employers' representatives also expressed a fear that separating 'green' from other forms of enterprises would lead to the stigmatisation of the latter as undesirable firms in terms of their environmental impact. They argued that the aim should not be to promote green enterprises and green jobs per se, but to work with the entire private sector towards more resilience and higher resource efficiency. This position reflected the concern in the private sector regarding strong environmental regulation from governments, particular in industrialised countries. In parallel, member states with emerging economies called for an enabling global policy environment (for trade openness and transfer of and access to technology and finance) without making the degree of 'greening' a condition of or obstacle to trade and their own economic growth.

Meanwhile, the workers' representatives argued consistently for a proactive role from the ILO, following the trade unions' own resolution on 'Combating Climate Change through Sustainable Development and Just Transition', at their second Congress, in Vancouver, 2010 (Rosemberg, 2013).

Despite these differences, the policy discussions on the ILO's Governing Board did not, in essence, reveal a fundamental disagreement at the level of the Organization with regard to the rationale for addressing the impact of climate change on the world of work. Rather, the debate was focused on how links to the decent work agenda could be made, what the unique value added by the ILO would be, and whether this would eventually lead to a new international labour standard regarding social justice in the context of the transition. A compromise was found, with the agreement to hold a General Discussion at the International Labour Conference in 2013, which would shape the policy agenda and review the available ILO instruments that might support a just transition.

At the same time, the parties to the United Nations Framework Convention on Climate Change (UNFCCC) included a specific reference to decent work in the 'shared vision' for a future global climate agreement, in Cancun, 2011. The year after, the Rio+2o outcome document- 'The Future We Want'established the key role of decent work for sustainable development in a dedicated chapter and through numerous cross references (UN, 2012). It identifies the concept of a green economy as one of the pathways to sustainable development and stresses that such an approach must lead to social inclusion and the creation of employment and decent work for all. It also acknowledges

7 This is consistent with the deliberations that led to the final Rio+2o outcome document'The Future We Want' (UN, 2012). 
'the importance of efforts to promote the exchange of information and knowledge on decent work for all and job creation, including green jobs initiatives and related skills, and to facilitate the integration of relevant data into national economic and employment policies' (UN, 2012, 29).

\subsection{ILO Follow-up to Rio+2o and Anticipation of the Paris Climate Agreement}

In the wake of Rio+20, the International Labour Conference of June 2013 adopted a landmark resolution with a set of conclusions on the relationship between sustainable development, decent work and green jobs (ILO, 2013a). The conclusions set out a common vision for achieving decent work, green jobs and sustainable development and provide guiding principles for the greening of economies, enterprises and jobs. Although not an international labour standard or convention that requires ratification by member states, the outcome signified the agreed normative guidance to constituents on how to effectively deal with the implications of climate change and environmental degradation for the labour market and for social protection.

The adoption and follow up to the 2013 conclusions also accelerated the mainstreaming of environmental concerns across all policy outcomes and country programmes within the ILO, leading to the inclusion of environmental sustainability as one of the four cross-cutting policy drivers in the Organization's Programme and Budget 2018-19 (ILO, 2017b).

The 2013 conclusions also define a basic policy framework to ensure a just transition for all. As a follow up, the ILO issued guidelines for a just transition towards environmentally sustainable economies and societies for all, formulated by a tripartite meeting of 24 experts, held in October 2015 in Geneva (ILO, 2015b). The Guidelines provide detailed suggestions in eight distinct policy areas to support national capacities for the design and implementation of transition measures, with the creation of decent work, poverty eradication and social inclusion.

The notion of just transition for the workforce was included in the preamble of the 2015 Paris Agreement. In turn, this led to the creation of an ad hoc UNFCCC Technical Expert Group on the impact of the implementation of response measures (UNFCCC, 2016).

In preparation for the ILO's centenary celebrations in 2019, seven Centenary Initiatives were launched, including the Green Initiative. The Director General devoted his personal report to the International Labour Conference of 2017 to 'Work in a Changing Climate' (ILO, 2017a). As part of the Green Initiative, the 2018 edition of the annual ILo World Employment and Social Outlook report 
(ILO, 2018), 'Greening with Jobs', was entirely devoted to the employment dimensions of the evolving green transformation, in both quantitative and qualitative terms. The report brought together fresh analysis at global, national and sectoral levels with regard to job gains, losses and transformations-where possible, disaggregated by gender. It was a timely contribution, in particular for countries turning their nationally determined commitments (NDCs) - made under the 2015 Paris Agreement to reduce emissions-into feasible national strategies and sectoral action plans.

\subsection{Drivers of the Green Policy Agenda}

There have been few comparable issues that have risen so rapidly on the ILO's policy agenda. In a span of ten years environmental sustainability has become a central policy concern, among others, and a structuring element for a growing number of operational programmes with dedicated staff.

The changing international context around climate change and the adoption of the SDGs has certainly helped catalyse this process. ILO constituents too are more conscious of the increasing threats of climate change, pollution and natural resource depletion. The proactive role of the International Trade Unions Congress has had a particularly dynamic effect in promoting climate change to its place high on the ILO's policy agenda. Despite different interests and sometimes opposing views, workers' and employers' delegates have been able, with the support of member states, to find a political compromise in the form of a Resolution with Conclusions and non-binding guidelines on a just transition, rather than developing a new international labour standard.

The changing landscape of international development assistance towards climate-related finance, especially the creation of the Green Climate Fund, has catalysed efforts to make the ILO eligible and 'fit for purpose' for obtaining climate finance.

Other, more internal factors have also contributed to the matter's rise in organisational priority - and popularity. Two successive ILo Directors General over 15 years with a deep concern for environmental sustainability showed strong political commitment to articulate the link with decent work at the highest organisational level. The Secretariat pursued a pragmatic approach combining high external visibility through flagship reports with strong internal advocacy and expanded staff capacity building. A strong emphasis on team work for knowledge sharing and the creation of synergies for the promotion of green jobs-as opposed to building up a stand-alone programme-has enabled a rapid proliferation across key departments and Field Offices. Finally, a consistent capacity building programme for increasing relevant 
competencies among staff has facilitated the intended mainstreaming of the green jobs agenda.

\section{$4 \quad$ Conclusion}

The success of achieving the goals of the 2015 Paris Agreement is predicated on the societal agreement to adopt deep changes in patterns of consumption and production. The required structural changes in economies will entail sectoral shifts and new business models. The effects on the volume and structure of employment will be unequally distributed across segments of labour markets. Supportive policies can cushion and facilitate the adjustment. At the same time, policies that stimulate innovation and entrepreneurship whilst generating well-educated workers can in themselves help trigger a faster transformation.

But the question of whether the loss of jobs will be offset by gains in emerging sectors and through improved business practices is not simply a mathematical equation. Those who stand to lose their jobs do not necessarily have the necessary access and capabilities to seize new employment opportunities. From a social equity perspective, the real issue to address is the distributional implications, across and within countries, of the transition to a low-carbon, climate resilient society. The factors that set this transition apart from other structural changes in society are its global scale and its urgency. The achievement of the emissions reduction target for a climate change scenario not exceeding 2 degrees Celsius will depend on the speed of a successful transition. As Schmitz puts it: 'this is the first transition in history that has to be achieved purposely and with a deadline' (Schmitz, 2015, 170).

From an initial ad hoc engagement on environmental sustainability at the time of major global conferences and events, the ILO has shown a more consistent and increasingly strategic focus over the last decade. Its work has helped improve global recognition of the significance of employment and the critical role of the actors of the world of work. This is perhaps most convincingly reflected in the adoption of the imperative of a just transition of the workforce' in the 2015 Paris Agreement and the incorporation of environmental sustainability as a cross-cutting policy driver in the entire spectrum of the Organization's work. As national governments become more engaged in setting the policy framework and designing sector reform in order to attain the emissions reductions each of them has signed up to in the 2015 Paris Agreement, they come to realise the intricacies of labour markets and the 
need to buffer shocks and facilitate the adjustment of enterprises, workers and communities.

Internally, the ILO has been successful in creating consensus, building operational capacity and rallying policy support for considering climate change and the greening of the economy throughout its departments and Field Offices. Progressively, the concept of 'green jobs' has been adapted and integrated into work programmes, in particular those related to employment promotion, skills upgrading and enterprise development. Most importantly, the concept has helped overcome the false dilemma of promoting jobs versus saving the planet.

The task ahead, however, goes far beyond assessing the number and quality of jobs affected or created by climate change and the related policies. Given the expected sectoral shifts in the economy there is a growing demand for anticipating and managing the distributional implications for employment and the equity of environmental policies. Incidentally, these changes will also reinforce domestic and international migration trends, bringing with them yet other policy challenges in terms of national security, resettlement and social inclusion.

A more systemic approach must embed environmental aspects in all areas of work in order to further enhance the ILO's relevance to the future world of work and its appeal to constituents and funding partners. This would certainly apply to employment promotion, sustainable enterprise development, entrepreneurship promotion and skills upgrading, etc. But new boundaries will need to be crossed to shape social protection policies and mechanisms in the context of vulnerabilities to climate change, for example, and enlarge the scope and outreach of safety and health in existing hazardous work — such as waste management-and new green economy occupations. The renewed attention to improving the productivity of firms and workers should incorporate a drive to enhance resource productivity, seeking to maximise synergies through employer-worker cooperation, among other approaches. In a broader context, work on promoting and enforcing labour standards through factory-level compliance along global supply chains could be reinforced by joining similar initiatives on environmental standards—such as Better Cotton. ${ }^{8}$

Averting the worst impacts of climate change and keeping the use of resources within planetary boundaries compels all international organisations to undertake a fundamental reflection regarding their role. For the ILO, this challenge is essentially a call for ensuring social justice in the evolving

8 See the website http://bettercotton.org/ (accessed on 11 June 2018). 
transition and chartering the course towards a sustainable future that is decent and green for all.

\section{References}

Altenburg, T. \& C. Assmann (eds.) (2017) Green Industrial Policy: Concept, Policies, Country Experiences (Geneva and Bonn: UN Environment and German Development Institute/Deutsches Institut für Entwicklungspolitik), http://www.un-page.org/files/ public/green_industrial_policy_book_aw_web.pdf (accessed on 30 July 2018).

Bowen, A. and K. Kuralbayeva (2015) Looking for green jobs: the impact of green growth on employment (London and Seoul: The Grantham Research Institute on Climate Change and The Global Green Growth Institute), http://www.lse.ac.uk/ GranthamInstitute/wp-content/uploads/2015/03/Looking-for-green-jobs_the -impact-of-green-growth-on-employment.pdf (accessed on 30 July 2018).

Brown, O. (2007) Climate change and forced migration: Observations, projections and implications (Geneva: International Institute for Environment and Development), http://www.iisd.org/sites/default/files/publications/climate_forced_migration.pdf (accessed on 30 July 2018).

Bureau of Labor Statistics (US) (2010) Measuring Green Jobs, https://www.bls.gov/ green (accessed on 1 March 2018).

Caldecott, B., O. Sartor and T. Spencer (2017) Lessons from previous 'Coal Transitions' High-level summary for decision makers (Paris and London: IDDRI and Climate Strategies), https://www.iddri.org/sites/default/files/import/publications/coal _synthesisreport_vo4.pdf (accessed on 30 July 2018).

GGGI (Global Green Growth Institute) (2017) Accelerating the transition to a new model of growth, GGGI Strategic Plan 2015-2020 (Seoul: GGGI), http://gggi.org/ wp-content/uploads/2014/10/GGGI_Strategic_Plan-v11-LOW_RES.pdf (accessed on 30 July 2018).

ILO (International Labour Organization) (2018) World Employment and Social Outlook 2018: Greening with jobs (Geneva: ILO), https://www.ilo.org/weso-greening/ documents/WESO_Greening_EN_web2.pdf (accessed on 30 July 2018).

ILO (2017a) Work in a changing climate: The Green Initiative, Report of the Director-General, International Labour Conference, 106th Session (Geneva: ILO), http://www.ilo.org/wcmsp5/groups/public/---ed_norm/---relconf/documents/ meetingdocument/wcms_554315.pdf (accessed on 30 July 2018).

ILO (2017b) Draft Programme and Budget for 2018-19 and other questions, Report II, International Labour Conference, 106th Session (Geneva: ILO), https://wwwilo .org/wcmsp5/groups/public/---ed_norm/---relconf/documents/ meetingdocument/wcms_553198.pdf (accessed on 30 July 2018). 
ILO (2017c) Gender, labour and a just transition towards environmentally sustainable economies and societies for all (Geneva: ILO), http://www.ilo.org/wcmsp5/groups/ public/---ed_protect/---protrav/---ilo_aids/documents/publication/wcms_592348 .pdf (accessed on 30 July 2018).

ILO (2017d) How to measure and model social and employment outcomes of climate and sustainable development policies, Green Jobs Assessment Institutions Network (GAIN) Training Guidebook (Geneva: ILO), https:/www.ilo.org/global/topics/ green-jobs/publications/WCMS_613934/lang--en/index.htm (accessed on $17 \mathrm{Au}-$ gust 2018).

ILO (2016) What is a green job?, 13 April, http://www.ilo.org/global/topics/green-jobs/ news/WCMS_220248/lang--en/index.htm (accessed on 16 August 2018).

ILO (2015a), ILO's assessments on green jobs potential, 15 January, http://www.ilo.org/ global/topics/green-jobs/publications/WCMS_19o963/lang--en/index.htm (accessed on 11 June 2018).

ILO (2015b) Guidelines for a just transition towards environmentally sustainable economies and societies for all (Geneva: ILO), https://www.ilo.org/wcmsp5/groups/ public/---ed_emp/---emp_ent/documents/publication/wcms_432859.pdf (accessed on 30 July 2018).

ILO (2013a) Sustainable development, decent work and green jobs, International Labour Conference, 102nd Session, Report V (Geneva: ILO), https://www.ilo.org/ilc/ ILCSessions/102/reports/reports-submitted/WCMS_207370/lang--en/index.htm (accessed on 20 August 2018).

ILO (2013b) Methodologies for assessing green jobs, Policy brief (Geneva: ILO), https://www.ilo.org/wcmsp5/groups/public/---ed_emp/---emp_ent/documents/ publication/wcms_176462.pdf (accessed on 30 July 2018).

ILO (2011) Skills for Green Jobs: A Global View (Geneva: ILO), https://www.ilo.org/ wcmsp5/groups/public/---dgreports/---dcomm/---publ/documents/publication/ wcms_159585.pdf (accessed on 30 July 2018).

ILO (2007) Decent Work for Sustainable Development, Director-General's introduction to the International Labour Conference (Geneva: ILO), http://www.ilo.org/public/ english/standards/relm/ilc/ilc96/pdf/rep-i-a.pdf (accessed on 30 July 2018).

ILO and OECD (Organisation for Economic Co-operation and Development) (2012) Sustainable development, green growth and quality employment: Realizing the potential for mutually reinforcing policies, Background paper for the Meeting of G2o Labour and Employment Ministers, Guadalajara, Mexico, 17-18 May, http://www .oecd.org/employment/emp/50318559.pdf (accessed on 30 July 2018).

IRENA (International Renewable Energy Agency) (2018) Renewable energy and jobs:Annual review (Abu Dhabi: IRENA), https://irena.org/-/media/Files/IRENA/Agency/ Publication/2018/May/IRENA_RE_Jobs_Annual_Review_2018.pdf (accessed on 13 August 2018). 
ITUC (International Trade Union Confederation) (2017) Just Transition - Where Are We Now and What's Next? A Guide to National Policies and International Climate Governance, Climate Justice Frontline Briefing, https://www.ituc-csi.org/IMG/pdf/ ituc_climate_justice_frontline_briefing_2017.pdf (accessed on 20 August 2018).

ITUC (2016)Just Transition Centre, https://www.ituc-csi.org/just-transition-centre (accessed on 1 March 2018).

Montt, G., N. Maître and S. Amo-Agye (2018) The transition in play: Worldwide employment trends in the electricity sector, Research Department Working Paper No. 28 (Geneva: ILO), http://www.oit.org/wcmsp5/groups/public/---dgreports/---inst/ documents/publication/wcms_625865.pdf (accessed on 23 August 2018).

OECD (Organisation for Economic Co-operation and Development) (2017) Investing in Climate, Investing in Growth (Paris: OECD), https://www.oecd.org/environment/ cc/g2o-climate/synthesis-investing-in-climate-investing-in-growth.pdf (accessed on 30 July 2018).

PAGHC (Platform for Advancing Green Human Capital) (2017) Advancing Green Human Capital, A Framework for Policy Analysis and Guidance, https://unevoc .unesco.org/up/Policy_Paper_PAGHC_draft_6Nov20176255.pdf (accessed on $17 \mathrm{Au}$ gust 2018).

Pociovălișteanu, D.M., I. Novo-Corti, M.I. Aceleanu, A.C. Șerban and E. Grecu (2015) 'Employment Policies for a Green Economy at the European Union Level', Sustainability, 7(7), pp. 9231-9250, DOI: 10.3390/su7079231.

Pollin, R. and B. Callaci (2016) The economics of just transition: A framework for supporting fossil fuel-dependent workers and communities in the United States (Amherst, MA: University of Massachusetts Amherst).

Rosemberg, A. (2013) 'Developing Global Union Environment Policies through the International Trade Union Congress', in N. Räthzel and D. Uzzel (eds.) Trade Unions in the Green Economy: Working for the Environment (Oxford: Routledge), pp. 15-28.

Schmitz, H. (2015) 'Green Transformation: Is There a Fast Track', in I. Scoones, M. Leach and P. Newell (eds.) The Politics of Green Transformations (Oxford: Routledge).

UN (United Nations) (2012) The Future We Want, Outcome of the United Nations Conference on Sustainable Development (Rio+2o), http://riozo.net/wp-content/uploads/ 2012/06/N1238164.pdf (accessed on 8 August 2018).

UNDP (United Nations Development Programme) (2016) Climate change and labour: impacts on heat in the workplace (New York: UNDP), http://www.ilo.org/wcmsp5/ groups/public/---ed_emp/---gjp/documents/publication/wcms_476194.pdf (accessed on 30 July 2018).

UNEP (United National Environment Programme) (2011) Towards a Green Economy: Pathways to Sustainable Development and Poverty Eradication, https://sustain abledevelopment.un.org $/$ index.php?page $=$ view $\&$ type $=400 \& n r=126 \& \mathrm{menu}=35(\mathrm{ac}-$ cessed on 10 August 2018). 
UNFCCC (United Nations Framework Convention on Climate Change) (2016) Just transition of the workforce, and the creation of decent work and quality jobs, UN doc. FCCC/TP/2016/7.

UNRISD (United Nations Research Institute for Development) (2012) Social Dimensions of Green Economy, Research and Policy Brief 12, https://www.files.ethz.ch/ isn/143941/RPB\%2012e.pdf (accessed on 30 July 2018).

van der Ree, K. (2017) Mainstreaming green job issues into national employment policies andimplementationplans:Areview,EmploymentWorkingPaperNo.227(Geneva:ILO), http://www.ilo.org/wcmsp5/groups/public/---ed_emp/documents/publication/ wcms_618884.pdf (accessed on 30 July 2018). 